\title{
Critical Factors for Run-up and Impact of the Tohoku Earthquake Tsunami
}

\author{
Efthymios Lekkas, Emmanouil Andreadakis*, Irene Kostaki, Eleni Kapourani \\ School of Science, Department of Dynamic, Tectonic and Applied Geology, \\ National and Kapodistrian University of Athens, Athens, Greece \\ E-mail: "eandreadk@geol.uoa.gr \\ Received April 20, 2011; revised May 27, 2011; accepted July 7, 2011
}

\begin{abstract}
The earthquake of March 11 of magnitude 9 offshore Tohoku, Japan, was followed by a tsunami wave with particularly destructive impact, over a coastal area extending approx. $850 \mathrm{~km}$ along the Pacific Coast of Honshu Island. First arrival times and measurements and maximum height were recorded by the Japanese monitoring system (wherever there was no failure of the equipment). The maximum run-up is well evident in satellite images available through USGS, Google and other institutes. Moreover, personal observations of Prof. Lekkas were made during a field survey in March 2011. The results of the study of the tsunami impact and run-up show the variety of factors affecting the run-up, creating zones with similar phenomena, but also specific locations where run-up exceeds by far the run-up zone maximum values. This differentiation, observed also in the past by other authors, is here attributed to the general orientation of the coast, the distance from the tsunami generation area, bathymetry offshore, the coastline morphology and land geomorphology. In certain cases that funnelling and reflection effects in narrow gulfs parallel to the tsunami propagation vector were combined with narrow valleys onshore, peak run-up exceeded 20m, or even $40 \mathrm{~m}$ (Miyagi coastline, Ogatsu, Onagawa, etc.).
\end{abstract}

Keywords: Tohoku, Earthquake, Tsunami, Run-Up

\section{Magnitude and Intensity of the Earthquake}

On March 11 2011, the tectonic boundary between the Pacific and Eurasian plates, off the coast of Northeastern Japan, ruptured in a great $(\mathrm{Mw}=9.0)$ earthquake, at 05:46:23 UTC (Universal Time Coordinated), 14:46:23 JST (Japan Standard Time) [1,2]. The hypocenter is calculated at $32 \mathrm{~km}$ by JMA [2] and $24 \mathrm{~km}$ by USGS depth [1]. Centroid Moment Tensor analysis showed a reverse fault type with WNW-ESE compressional axis, corresponding to depth and orientation of the Japan Trench [2]. Main rupture was located in the North-East of the rupture starting point (shallower side of the hypocenter), and maximum slip amounted to about $25 \mathrm{~m}$ [2]. The size of the main fault is estimated at $450 \mathrm{~km}$ length and $150 \mathrm{~km}$ width, confirmed by first day aftershock locations. Nearsource acceleration waveforms by National Research Institute for Earth Science and Disaster Prevention (NIED) [3], display two distinct phases of ground motion, which suggest the existence of at least two areas of large slip. Apparently, the focus belongs to the off Miyagi area of subduction zone earthquakes. The main shock triggered a major tsunami that swept the Eastern shoreline of Honshu (main island). The main shock was preceded by numerous foreshocks, the greatest of which occurred on March 9, 2011 and had a magnitude of 7.5 [2]. The focal mechanism of the earthquake is also consistent with a subduction zone boundary. A large number of aftershocks occurred, four of which measured $\mathrm{Mw}>7.0$. The first of these aftershocks occurred quite soon (aprox. 30 min.) after the main shock and it measured 7.4, and three more major ones measured 7.7, 7.5 and 7.4 [2].

A maximum seismic intensity of 7 (JMA scale) was recorded at Kurihara City, Miyagi Prefecture. JMA intensities of 6+ or 6- were observed in wide area along East Honshu coast, in Iwate, Miyagi, Fukushima and Ibaraki prefectures (Figure 1) [2]. The meisoseismal area extends within the tectonic boundaries of $\mathrm{N}$. American-Okhotsk plate, that is, on the upper block of the rupture, as expected. 


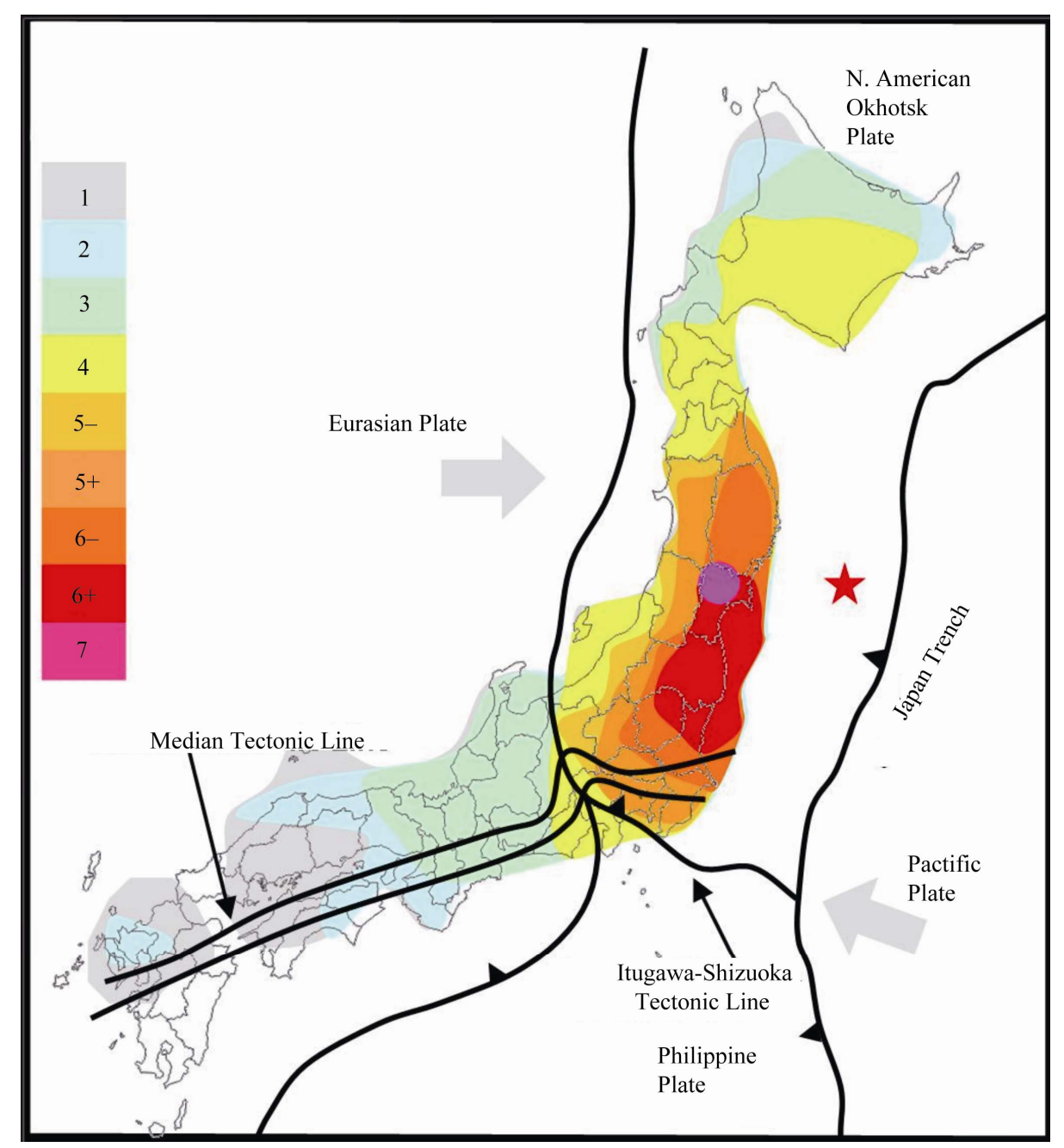

Figure 1. Intensity map for the 9.0 Mw event of March 11, 2011 (Data from JMA, map by authors). The Japanese intensity scale is used here, so this does not correspond to EMS or Mercalli intensities but instead it reflects measured seismic acceleration distribution.

\section{Tsunami Characteristics}

Tohoku was hit by tsunami intensities ranging in the worst cases from IX up to XI (or even XII) in the Papadopoulos-Imamura (2001) scale [4]. That is, in the worst of cases (XII intensity tsunami) all masonry buildings were demolished. From XI intensity up, floodwater backwash has drifted all debris, cars etc. to the sea and objects of all sizes were deposited as sediment into low lying coastal areas. This took place especially where backwash was obstructed by obstacles such as embankments, hills, forested areas, elevated roads etc. and in areas that had subsided below sea level.

Coastal subsidence due to earthquake deformation was measured by the Geospatial Information Authority of Japan [5], showing a maximum of $2 \mathrm{~m}$ subsidence offshore and a maximum of $1-1.5 \mathrm{~m}$ onshore, namely at Ishinomaki area, Miyagi prefecture and Ojika peninsula.
A vertical deformation of $1.2 \mathrm{~m}$ was measured at Ojika peninsula. These areas suffered thousands of casualties because of the tsunami inundation, since the tsunami wave arrived at offshore Miyagi area first, combined with the maximum observed subsidence. Even greater uplift was observed at the easternmost part of the Eurasian plate, until the Japan Trench. Maximum uplift was measured over $4.5 \mathrm{~m}, 20 \mathrm{~km}$ east of the epicentral area (Figure 2).

JMA issued the first tsunami arrival, recorded at 14:45 JST at Kamaishi, Iwate prefecture, as a sea withdrawal $[6,7]$. The fact that the first tsunami arrival is recorded simultaneously or even earlier than the earthquake waves themselves may be an indication of crustal deformation, subsidence as a result of the earthquake rupture.

First actual tsunami arrival is recorded at Ishinomaki, Miyagi prefecture, at 14:46 JST with a measured height of $0.1 \mathrm{~m}$. 


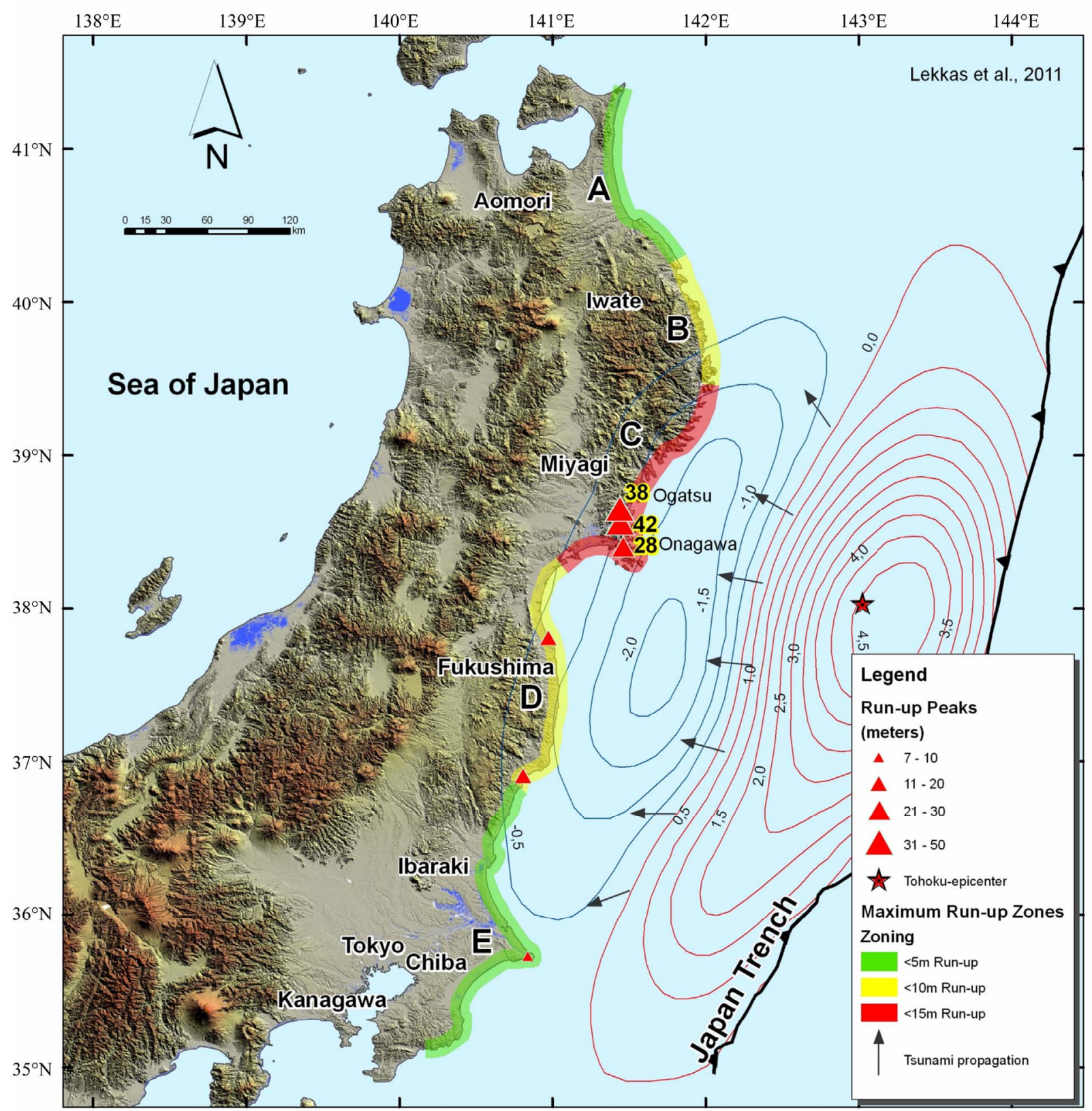

Figure 2. Tsunami run-up zones for the Tohoku earthquake 11-3-2011. Propagation vectors are marked with black arrows, indicative peak run-ups are marked with red triangles and run-up values with black-yellow numbers. Contour lines show crust uplift (red) and subsidence (blue) in meters. The maximum runup zones indicate areas where runup generally did not exceed the indicated elevation, except for the cases of peaks, due to local conditions, discussed in the text.

The maximum tsunami height was recorded by JMA at Miyako, Iwate prefecture, at March 11 2011, 15:26 JST reaching a height of $8.5 \mathrm{~m}$. It is clear that tsunami run-up reached a greater height, as concluded by field surveying and disasters. However, estimations of tsunami height are higher than the ones recorded by JMA. Port and Airport Research Institute (PARI) reports inundation up to $14.8 \mathrm{~m}$ (Onagawa port) [8]. This is not so surprising though, if one takes into account that almost one kilometer inland, the tsunami height was measured to more than $10 \mathrm{~m}$ (Figure 5).

Run-up is defined as "the maximum vertical elevation of a point on initially dry land that is inundated by the waves" [9]. The measurements in Table 1 show first arrival and maximum height in Hokkaido Prefecture (Hokkaido Island north of Honshu Island) and Aomori, Iwate, Miyagi, Fukushima, and Ibaraki Prefectures, along East coast of Honshu, from North to South [6,7]. A 
Table 1. First arrival times and heights and maximum measured heights of tsunami wave as recorded by JMA, from Hokkaido, Aomori, Iwate, Miyagi, Fukushima and Ibaraki Prefectures.

\begin{tabular}{|c|c|c|c|c|}
\hline Location & Date/Time (JST) & First arrival height (m) & Date/Time (JST) & Maximum measured height (m) \\
\hline \multicolumn{5}{|c|}{ Earthquake occurrence 11 March 14:46 } \\
\hline Nemuro (Hokkaido Pref.) & 11 March 15:34 & $<+0.1 \mathrm{~m}$ & 11 March 15:57 & $+2.8 \mathrm{~m}$ \\
\hline Tokachi (Hokkaido Pref.) & 11 March 15:26 & $-0.2 \mathrm{~m}$ & 11 March 15:57 & $>+2.8 \mathrm{~m}$ \\
\hline Urakawa (Hokkaido Pref.) & 11 March 15:19 & $-0.2 \mathrm{~m}$ & 11 March 16:42 & $+2.7 \mathrm{~m}$ \\
\hline Mutsu (Aomori Pref.) & 11 March 15:20 & $-0.1 \mathrm{~m}$ & 11 March 18:16 & $+2.9 \mathrm{~m}$ \\
\hline Miyako (Iwate Pref.) & 11 March 14:48 & $+0.2 \mathrm{~m}$ & 11 March 15:26 & $>8.5 \mathrm{~m}$ \\
\hline Kamaishi (Iwate Pref.) & 11 March 14:45 & $-0.1 \mathrm{~m}$ & 11 March 15:21 & $>+4.1 \mathrm{~m}$ \\
\hline Ofunato (Iwate Pref.) & 11 March 14:46 & $-0.2 \mathrm{~m}$ & 11 March 15:18 & $>8.0 \mathrm{~m}$ \\
\hline Ishinomaki (Miyagi Pref.) & 11 March 14:46 & $+0.1 \mathrm{~m}$ & 11 March 15:25 & $>+7.6 \mathrm{~m}$ \\
\hline Soma (Fukushima Pref.) & 11 March 14:55 & $+0.3 \mathrm{~m}$ & 11 March 15:50 & $>+7.3 \mathrm{~m}$ \\
\hline Oarai (Ibaraki Pref.) & 11 March 15:15 & $+1.8 \mathrm{~m}$ & 11 March 16:52 & $+4.2 \mathrm{~m}$ \\
\hline
\end{tabular}

great percentage of Eastern Honshu low-lying coastal areas were inundated by the tsunami wave. Ibaraki and Chiba prefectures were less inundated than the northern areas (Chiba less than Ibaraki), mainly due to increased distance to tsunami generation area, less crust deformation and coastal orientation (Chiba).

Inundation refers to the maximum horizontal penetration of the waves in the direction perpendicular to the beach, during the flooding [9]. The identification of a data point characterizing water penetration can be made either on the basis of the recognition of a specific watermark, such as a debris line deposited by the wave, either on land or in vegetation, or through personal reports from eyewitnesses. On occasion, it may be possible to determine neither run-up, nor inundation, but only to infer the local flow depth, usually from watermarks on the sides of walls or from debris left dangling on trees or posts.

The tsunami generation area extended for several hundred kilometers along the uplift zone of the crust deformation area. The combination of uplift and subsidence zones instantly built up a potential difference that reached the maximum of 6.5 meters offshore, initiating the wave. Run-up was zoned along the meisoseismal area of Tohoku coast, creating five major zones. A maximum run-up zone developed at Miyagi coast and South Iwate coast (zone C), two medium run-up zones extended along North Iwate coast and Fukushima coast (zones B and $\mathrm{D}$ respectively) and two minimum run-up zones extended at Aomori coast, and the coast of Ibaraki and Chiba (zones A and E).

\section{Peak Run-Up Locations}

Field observations in Tohoku, and especially Miyagi, Fukushima, Ibaraki and Iwate prefectures, showed that there are many areas where run-up exceeded the general maximum value by far. That is, in Miyagi, where maximum run-up was generally below $15 \mathrm{~m}$, there were locations that it reached more than 20, 30 or 40 meters. It was observed that this happened in small valleys with rather high slope angle, which are in fact the inland continuation of respective similar shaped bays and small gulfs. In the following (Figures 3, 4, 5) the highest observed run-up locations are shown in Ogatsu and Onagawa, where run-up exceeded 30 and 40 meters respectively.

\section{Discussion}

A large amount of data and thorough research on tsunami generation, propagation and inland propagation derived from various researchers and sources, especially in the recent decades, and mostly after the Indonesian tsunami of 2004. The latter, gave the opportunity of investigation along all kinds of distances from the source, along several kinds of shoreline and bathymetries and in areas with a wide range of magnitudes for tsunami run-up, inundation and depth. The parameters examined for their implication on tsunami run-up for the Tohoku earthquake in this paper, have been individually or generally analyzed and reviewed by many for previous cases. Thus, some of their conclusions can be compared to observations of the present investigation.

Geist [9] summarizes some of these conclusions of previous investigations on the subject. Carrier [10] suggests that the largest tsunami amplitudes in many cases are traced to the direct arrival of the tsunami broadside from the rupture area, while, along shoreline segments oblique to the rupture area, the largest tsunami amplitudes are attributed to the excitation and propagation of edge waves [10-13] (trapped long waves analogous to 
Table 2. Comparative data for the tsunami run-up zones after the Tohoku earthquake.

\begin{tabular}{|c|c|c|c|c|c|c|c|c|}
\hline Zone & Area & $\begin{array}{l}\text { Average max. } \\
\text { Run-up (m) }\end{array}$ & $\begin{array}{c}\text { Run-up } \\
\text { peaks (m) }\end{array}$ & $\begin{array}{c}\text { Tsunami propagation } \\
\text { vector vs. shoreline } \\
\text { direction }\end{array}$ & $\begin{array}{c}\text { Minimum } \\
\text { Distance from } \\
\text { epicentre }(\mathbf{k m})\end{array}$ & $\begin{array}{c}\text { Minimum } \\
\text { Distance from } \\
\text { offshore uplift } \\
\text { (km) }\end{array}$ & $\begin{array}{c}\text { Subsidence } \\
\text { onshore (m) }\end{array}$ & $\begin{array}{c}\text { Maximum } \\
\text { Uplift offshore } \\
\text { (m) }\end{array}$ \\
\hline B & N. Iwate & $<10$ & & Subparallel - Diagonal & 180 & 78 & $0.5-1.0$ & $0.5-1.0$ \\
\hline $\mathrm{C}$ & S. Iwate, Miyagi & $<15$ & 42, 37, 28 & Perpendicular & 132 & 70 & $1.0-1.5$ & 4.5 \\
\hline $\mathrm{E}$ & Ibaraki & $<5$ & 7 & $\begin{array}{l}\text { Perpendicular - } \\
\text { Diagonal }\end{array}$ & 240 & 40 & $0.0-0.5$ & $1.0-2.0$ \\
\hline $\mathrm{E}$ & Chiba & $<5$ & & Subparallel & 322 & 40 & $0.0-0.5$ & $0.0-0.5$ \\
\hline
\end{tabular}

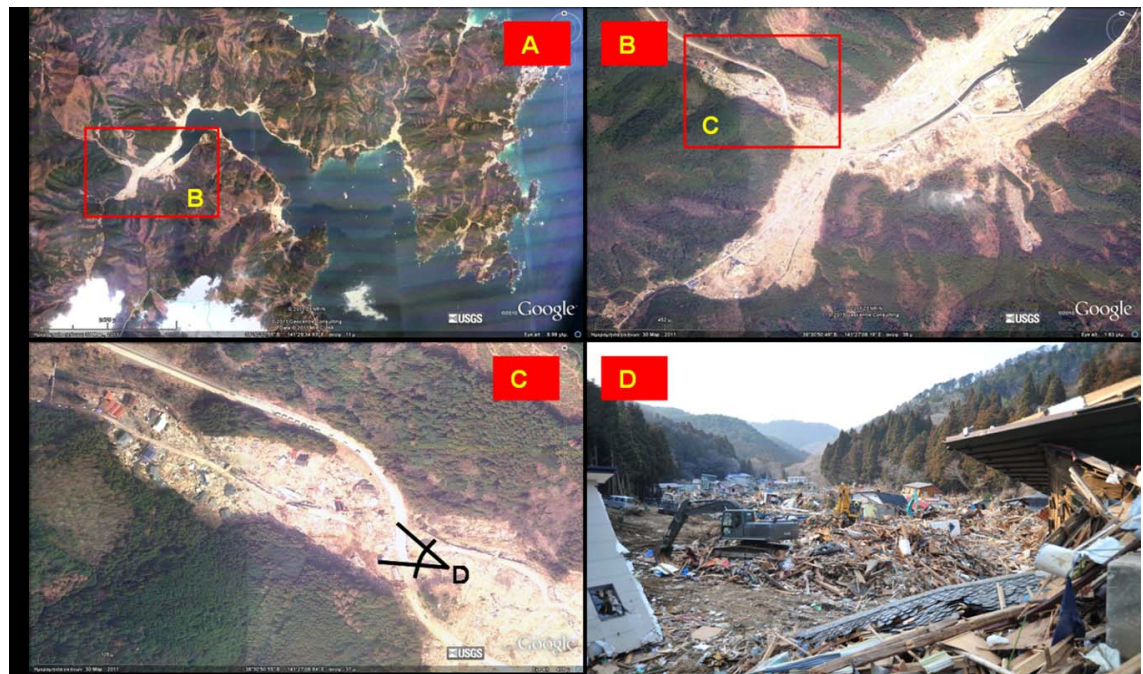

Figure 3. Three satellite images in subsequent zoom-in and a photo, from Ogatsu-Wan and Ogatsu town (Miyagi, zone C, 15m maximum run-up). Bathymetry and onshore geomorphology created funneling effects and wave reflection within the canyon and narrow valleys enhanced the tsunami effects. As a result, peak run-up reached the elevation of $38 \mathrm{~m}$. Not only did the tsunami reach this elevation, but it arrived with several meters of height, performing a totally devastating run (Photos A, B, C from Google Earth, photo D by E. Lekkas during the field trip to Japan).

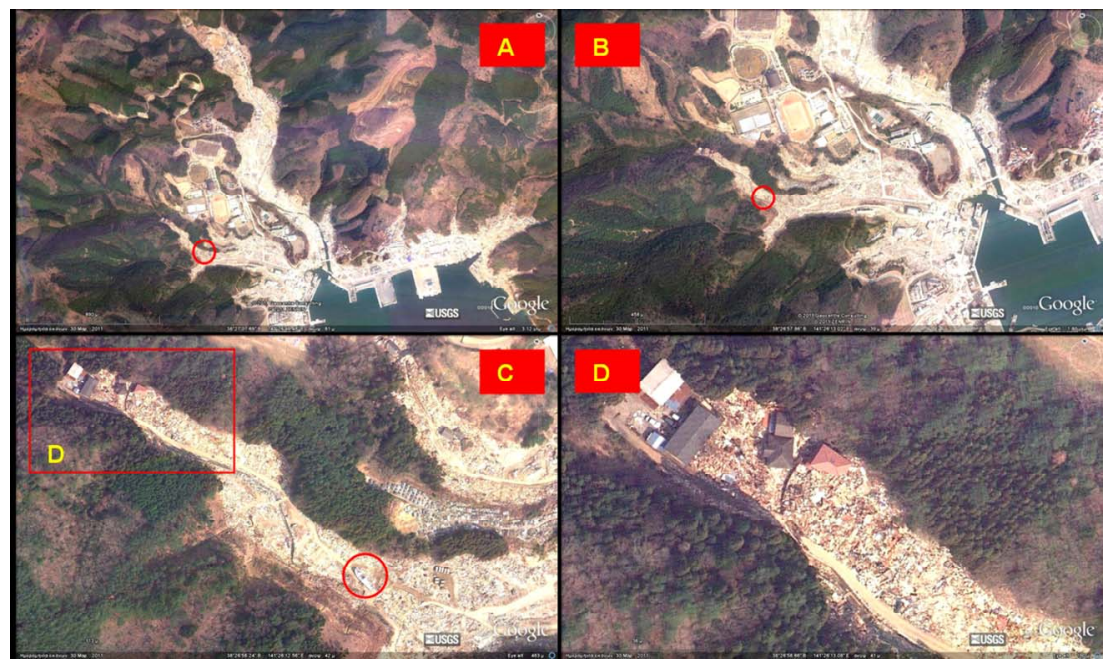

Figure 4. Four satellite images in subsequent zoom-in, from Onagawa Wan and Onagawa town (Miyagi, zone C, 15 maximum run-up). For the same reasons as for Ogatsu, Onagawa was hit by extremely disastrous tsunami run-up reaching 42 meters. In the red circles (photos A, B and C) a $30 \mathrm{~m}$ long vessel is shown, at a distance of 750 meters from the coast (elevation $21 \mathrm{~m}$ ). 


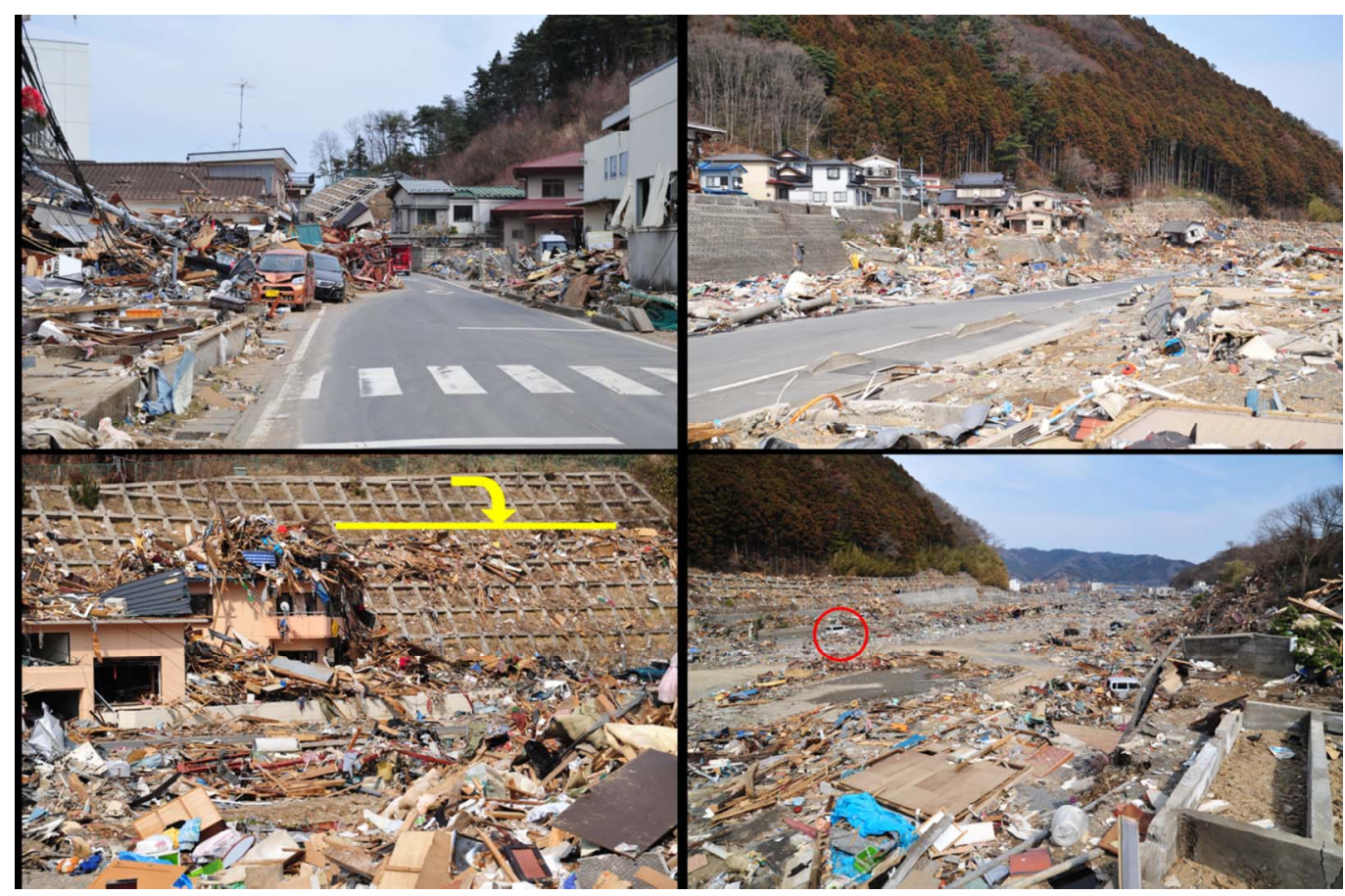

Figure 5. Onagawa town. At least $10 \mathrm{~m}$ of wave height swept away the whole "corridor" within the narrow valley. The red circle indicates the position of a van.

Love waves in seismology [14]). Ishii and Abe suggest that phase and group velocities of edge waves depend on the shelf slope angle [15]. For irregular coastlines, edge waves will be scattered and reflected and, where these different phases (trapped and nontrapped) interfere constructively and at antipodes, large nearshore tsunami amplitudes can be realized.

Lavigne et al. [16,17] report that marine surveys after the 2004 tsunami refer that uniformity of tsunami runup indicates that there is limited co-seismic landslide presence involved. They conclude that local geomorphological configurations of the coastline and/or the seafloor were responsible for exceptional runup heights along the west coast of the Banda Aceh district (Indonesia).

Pattiaratchi and Wijeratne (2009) [18] studied sealevel records during the Indonesian tsunami at stations on Sri Lanka and Australia. They showed that similar tsunami behaviour responds to similar local and regional topography, although the relative magnitude of the tsunamis varies according to the differences of the source.

Synolakis et al. [19], Duong et al. [20], Jinadasa [21], Parcharidis et al. [22] and Yeh et al. [23], among many others studied the Indian Ocean tsunami, reaching similar results after investigations along the affected areas.

\section{Conclusions}

Tsunami run-up zoning and peaks are the result of a combination of factors, summarized at the following:
- Orientation of the propagation vector to the mean shoreline direction. Run-up was higher at areas where the tsunami propagation vector was perpendicular to the main shoreline direction. This took place at the areas of South Iwate, Miyagi, Fukushima and a part of Ibaraki coast. Oblique shorelines were generally affected by lower run-up, and as it seems by the map zonation, this parameter along with the distance from the source created the first order effects, as far as run-up is concerned, in this case, once the run-up peaks are observed within the broader zones mapped.

- Distance from the tsunami generation area. Energy of tsunami wave is consumed along the way, so the shorter the distance, the higher the tsunami energy, and the higher the run-up. The shortest distances from the epicenter were from South Iwate and Miyagi, while the shortest distances from the nearest uplift area were from Ibaraki, Chiba and Miyagi. Of course it is difficult to discriminate which of these two (orientation or distance) was the dominant parameter, once both distance and obliquity of shorelines are increased laterally from the meisoseismal area towards north and south.

- Bathymetry of the offshore area. Coastal geomorphology, bathymetry and seafloor topography are believed to be the major influencing factors to determine the severity of tsunami disasters, as well as narrow continental shelves and canyons. On the contrary, natural barriers and coral reefs protect the coasts from 
tsunamis. In major canyons, funneling effects and overlapping reflections further enhance tsunami height.

- Land morphology actually proved to enhance run-up in the same way as bathymetry. That is, the highest peaks of tsunami run-up were observed where narrow, short, funnel-like valleys reached the coastline with a direction parallel to the tsunami propagation vector. Run-up in these areas exceeded by far the zone maximum, due to the particularities of geomorphology. For instance, within the $15 \mathrm{~m}$ maximum run-up zone, altitudes of $28 \mathrm{~m}, 38 \mathrm{~m}$ and $42 \mathrm{~m}$ were observed at Ogatsu and Onagawa (Miyagi prefecture).

- Crustal deformation during the event, which was simply mentioned here as a simple potential differentiation during the quake (like an instant change of hydraulic head in adjacent areas) has to be further investigated as a factor for run-up. The size of the area and the magnitude of the deformation suggest a very large scale tsunami generation area, where the source mechanism itself would have to be examined as a whole.

\section{References}

[1] U. S. Geological Survey Magnitude 9.0, "Near the East Coast of Honshu,” Japan. http://earthquake.usgs.gov/ (accessed at April 2011).

[2] Japan Meteorological Agency, "Tohoku Region Pacific Ocean Earthquake Report 1-34, March 11- April 8 2011,” in Japanese, 2011. http://www.jma.go.jp (last accessed April 2011).

[3] National Research Institute for Earth Science and Disaster Prevention, "2011 Off the Pacific Coast of Tohoku earthquake, Strong Ground Motion,” Emergency Meeting of Headquarters for Earthquake Research Promotion, March 13, 2011.

http://www.bosai.go.jp/e/ (accessed April 2011).

[4] G. Papadopoulos and F. Imamura, "A Proposal for a New Tsunami Intensity Scale,” ITS 2001 Proceedings, Session 5, No. 5-1, 2001, pp. 569-577.

[5] Geospatial Information Authority of Japan, “The 2011 off the Pacific Coast of Tohoku Earthquake: Coseismic Slip Distribution Model (Preliminary),” 2011. http://www.gsi.go.jp (last accessed April 2011).

[6] Japan Meteorological Agency, "The 2011 off the Pacific Coast of Tohoku Earthquake,” 2011.

http://www.jma.go.jp/jma/en/2011_Earthquake.html (last accessed April 2011).

[7] Japan Meteorological Agency, "Tsunami Observation Stations Report: Miyako, Ofunato. 23 March 2011,” in Japanese, 2011. http://www.jma.go.jp, (last accessed April 2011).

[8] Port and Airport Research Insitute (PARI), "Executive Summary of Urgent Field Survey of Earthquake and Tsunami Disasters by the 2011 off the Pacific Coast of Tohoku Earthquake,” March 25, 2011. http://www.pari.go.jp/, last accessed April 2011.

[9] E. L. Geist, "Complex Earthquake Rupture and Local Tsu- Namis,” Journal of Geophysical Research, Vol. 107, 2002, pp. 2086-2101. doi:10.1029/2000JB000139

[10] G. F. Carrier, "On-Shelf Tsunami Generation and Coastal Propagation, in Tsunami,” In: Y. Tsuchiya and N. Shuto, Eds, Progress in Prediction, Disaster Prevention and Warning, Kluwer Academy Publishing, Norwell, 1995. pp. 1-20,

[11] J. D. Fuller and L. A. Mysak, "Edge Waves in the Presence of an Irregular Coastline,” Journal of Physical Oceanography, Vol. 7, No. 6, 1977, pp. 846-855. doi:10.1175/1520-0485(1977)007<0846:EWITPO>2.0.C $\underline{\mathrm{O} ; 2}$

[12] F. I. Gonzalez, K. Satake, F. Boss and H. O. Mofjeld, "Edge Wave and Non-Trapped Modes of the 25 April 1992 Cape Mendocino Tsunami,” Earth and Environmental Science, Vol. 144, No. 3-4, 1995, pp. 409-426. doi:10.1007/BF00874375

[13] K. Fujima, R. Dozono and T. Shigemura, “Generation and Propagation of Tsunami Accompanying Edge Waves on a Uniform Sloping Shelf,” Coastal Engineering, Vol. 42, 2000, pp. 211-236.

[14] K. Sezawa and K. Kanai, "On Shallow Water Waves Transmitted in the Direction Parallel to a Sea Coast, with Special Reference to Love-Waves in Heterogeneous Media,” Bulletin of the Earthquake Research Institution, Vol. 17, 1939, pp. 685-694.

[15] H. Ishii and K. Abe, "Propagation of tsunami on a linear slope between two flat regions, part I, Edge wave," Journal of Physics of the Earth, Vol. 28, No. 5, 1980, pp. 531-541. doi:10.4294/jpe1952.28.531

[16] P. R. Cummins, L. S. L. Kong and K. Satake, "Introduction to "Tsunami Science Four Years after the 2004 Indian Ocean Tsunami, Part II: Observation and Data Analysis,” Pure and Applied Geophysics, Vol. 165, No. 11-12, 2009.

[17] F. Lavigne, et al., "Reconstruction of Tsunami Inland Propagation on December 26, 2004 in Banda Aceh, Indonesia, through Field Investigations,” Pure and Applied Geophysics, Vol. 166, No. 1-2, 2009, pp. 259-281. doi:10.1007/s00024-008-0431-8

[18] C. B. Pattiaratchi and E. M. S. Wijeratne, "Tide gauge observations of the 2004-2007 Indian Ocean tsunamis from Sri Lanka and western Australia,” Pure and Applied Geophysics, Vol. 166, No. 1-2, 2009, pp. 233-258. doi:10.1007/s00024-008-0434-5

[19] C. E. Synolakis and L. Kong, "Runup of the December 2001 Indian Ocean Tsunami,” Earthquake Spectra, Vol. 22, 2006, pp. S67-S91.

[20] N. A Duong, F. Kimata and I. Meilano, “Assessment of Bathymetry Effects on Tsunami Propagation in Viet Nam," Advances in Natural Sciences, Vol. 9, No. 6, 2008.

[21] S. U. P. Jinadasa, "Interaction of Tsunami Wave Propagation with Coastal Bathymetry and Geomorphology: A Case Study in Sri Lanka,” Hydrographic and Oceanographic Department, Japan Coast Guard, Tokyo, 2008. 
[22] I. Parcharidis, E. Lekkas, and M. Foumelis, “Tsunami Impact Depending on Coastal Morphology: The Case of Phuchet Island and Khao Lac Coast (Thailand),” International Symposium on the Geodynamics of Eastern Mediterranean: Active Tectonics of the Aegean Region. Istanbul, 2005, 238.
[23] H. Yeh, R. K. Chadha, M. Francis, T. Katada, G. Latha, C. Peterson, G. Raghuraman and J. P. Singh, "Tsunami Runup Survey along the Southeast Indian Coast”, Earthquake Spectra, Vol. 22, No. S3, 2006, pp. S173-S186. doi:10.1193/1.2202651 